\title{
Anticonvulsant peripheral neuropathy: a clinical and electrophysiological study of patients on single drug treatment with phenytoin, carbamazepine or barbiturates
}

\author{
SD SHORVON,$^{*}$ EH REYNOLDS \\ From the University Department of Neurology, Institute of Psychiatry and Kings College Hospital Medical \\ School, London, UK
}

SUMMARY Previous studies of phenytoin neuropathy in selected groups of chronic epileptic patients on polytherapy have indicated a widely varying incidence of clinical or electrophysiological abnormalities. In 51 previously untreated epileptic patients followed prospectively on phenytoin or carbamazepine monotherapy, assisted by blood level monitoring, for 1-5 years we found no clinical evidence of neuropathy. Eighteen per cent of the phenytoin group and none of the carbamazepine group had mild electrophysiological changes (abnormalities of sensory action potentials or sensory conduction). In the former group the occurrence of the electrophysiological abnormalities was possibly related to previous exposure to high phenytoin or low folate levels or both. In 10 chronic epileptic patients we demonstrated reversible slowing of sensory nerve conduction during phenytoin intoxication. In six selected epileptic patients on chronic barbiturate monotherapy we found clinical evidence of neuropathy in two and electrophysiological abnormalities in five, including reversible slowing of sensory conduction during intoxication in one. This suggests that barbiturate drugs may, like phenytoin, also contribute to anticonvulsant neuropathy. Careful monitoring of single drug therapy with avoidance of acute toxicity may reduce the risk of chronic anticonvulsant neuropathy.

Isolated cases of peripheral neuropathy associated with phenytoin therapy in epileptic patients have been reported over many years. ${ }^{1-5}$ However, only in the last 15 years has the subject been investigated in detail. Since the negative study of Brumlik and Moretti $^{8}$ there have been several further clinical and/or electrophysiological investigations in groups of chronic epileptic patients ${ }^{7-18}$ which are summarised in table 1 . These reports have produced widely varying observations regarding the incidence ( $0-33 \%$ clinical, and $0-89 \%$ electrophysiological) and nature of phenytoin neuropathy. These apparently conflicting conclusions may have arisen because there are

Address for reprint requests: Dr EH Reynolds, Department of Neurology, Kings College Hospital, Denmark Hill, London SE5 9RS, UK.

*Present address: The National Hospital for Nervous Diseases, Queen Square, London WC1.

Received 25 September 1981 and in revised form 1 January 1982. Accepted 30 January 1982. several important aspects of the subject which have received inadequate attention.

First, it has been clearly established that exposure to high serum levels of phenytoin may cause an immediate and reversible slowing of nerve conduction, and this must be differentiated from the permanent electrical changes of chronic peripheral neuropathy. This acute effect was first reported in animal and in vitro experiments $\mathrm{s}^{14-17}$ and has been demonstrated in two human studies. Hopf ${ }^{18}$ reported a reversible slowing in nerve conduction in human volunteers after 11 days of treatment with phenytoin, and although serum levels were not measured the drug doses were high. Birket-Smith and $\mathrm{Krogh}^{19}$ found a reversible slowing of motor conduction in 19 patients that was apparent only with serum phenytoin levels above $120 \mu \mathrm{mol} / \mathrm{l}$. This phenomenon has been overlooked in many of the previous reports of phenytoin neuropathy. For example, of the 20 patients with lower limb areflexia reported by Lovelace and Horwitz, ${ }^{12}$ only two showed no evidence of toxicity and 
Table 1 Previous clinical and electrophysiological studies of phenytoin induced peripheral neuropathy

\begin{tabular}{|c|c|c|c|c|c|c|c|c|c|c|}
\hline \multirow[t]{2}{*}{ Authors } & \multirow{2}{*}{$\underline{N}$} & \multicolumn{2}{|l|}{ Patients } & \multicolumn{4}{|c|}{ Other aspects of study design } & \multicolumn{3}{|l|}{ Findings } \\
\hline & & $\begin{array}{l}\text { Age range } \\
\text { (years) }\end{array}$ & $\begin{array}{l}\text { Length of } \\
\text { phenytoin } \\
\text { treatment } \\
\text { (years) }\end{array}$ & $\begin{array}{l}\text { High } \\
\text { serum } \\
\text { phenytoin } \\
\text { levels }\end{array}$ & $\begin{array}{l}\text { Phenytoin } \\
\text { mono- } \\
\text { therapy }\end{array}$ & $\begin{array}{l}\text { Folate } \\
\text { levels }\end{array}$ & $\begin{array}{l}\text { Control } \\
\text { group }\end{array}$ & $\begin{array}{l}\text { Incidence of } \\
\text { clinical } \\
\text { neuropathy }\end{array}$ & $\begin{array}{l}\text { Incidence of } \\
\text { electro- } \\
\text { physiological } \\
\text { abnormality }\end{array}$ & Relationships \\
\hline Brumlik \& Moretti $(1966)^{6}$ & 26 & $16-57$ & $0 \cdot 25-25$ & - & - & - & + & Nil & $\begin{array}{l}\text { No slowing of } \\
\text { median or ulnar } \\
\text { nerve conduction }\end{array}$ & $\mathrm{Nil}$ \\
\hline Lovelace \& Horwitz (1968) ${ }^{12}$ & 26 & $12-50$ & $>5$ & - & - & + & - & $\begin{array}{l}\text { Lower limb } \\
\text { areflexia in } 18 \%\end{array}$ & $\begin{array}{l}\text { Slowing of } \\
\text { motor con- } \\
\text { duction in } 95 \% \\
\text { of areflexic } \\
\text { patients }\end{array}$ & $\begin{array}{l}\text { Motor conduction } \\
\text { velocity inversely } \\
\text { related to } \\
\text { duration of } \\
\text { therapy }\end{array}$ \\
\hline DeCastro et al $(1972)^{8}$ & 11 & $17-52$ & $3-18$ & - & - & - & + & Not stated & $\begin{array}{l}\text { Slowing of } \\
\text { motor and } \\
\text { sensory con- } \\
\text { duction in } \\
72 \cdot 5 \%\end{array}$ & $\begin{array}{l}\text { Motor conduction } \\
\text { velocity inversely } \\
\text { related to } \\
\text { duration of } \\
\text { therapy }\end{array}$ \\
\hline Eisen et al $(1974)^{\circ}$ & 45 & $21-74$ & 10 & + & - & - & - & $\begin{array}{l}33 \% \text { lower-limb } \\
\text { areflexia and/ } \\
\text { or sensory } \\
\text { disturbance }\end{array}$ & $\begin{array}{l}89 \% \text { some } \\
\text { electrophysio- } \\
\text { logical changes }\end{array}$ & $\begin{array}{l}\text { Electrophysio- } \\
\text { logical and clinical } \\
\text { changes related to } \\
\text { high serum level } \\
\text { and high } \\
\text { phenytoin intake }\end{array}$ \\
\hline Encinoza $(1974)^{10}$ & 300 & $12-65$ & $2 \cdot 5-9$ & - & - & - & - & Nil & $\begin{array}{l}52 \% \text { some } \\
\text { electrophysio- } \\
\text { logical changes }\end{array}$ & $\begin{array}{l}\text { Electrophysio- } \\
\text { logical } \\
\text { abnormality } \\
\text { related to dose, } \\
\text { duration of } \\
\text { therapy and age }\end{array}$ \\
\hline Chokroverty \& Sayeed $(1975)^{7}$ & 35 & $17-58$ & $1-27$ & + & - & + & - & $\begin{array}{l}8 \cdot 5 \% \text { lower limb } \\
\text { areflexia and/ } \\
\text { or sensory loss }\end{array}$ & $\begin{array}{l}\text { Not clearly } \\
\text { stated }\end{array}$ & $\begin{array}{l}\text { Electrophysio- } \\
\text { logical } \\
\text { abnormality } \\
\text { related to } \\
\text { duration of } \\
\text { therapy and high } \\
\text { phenytoin levels }\end{array}$ \\
\hline Zebrowska-Szymusik (1978) ${ }^{13}$ & 42 & $19-44$ & $7-33$ & - & - & - & - & Nil & $7 \cdot 1 \%$ & $\begin{array}{l}\text { No relation to } \\
\text { serum level, } \\
\text { duration of } \\
\text { treatment, side } \\
\text { effects }\end{array}$ \\
\hline Fujiwara et al (1979) & 40 & $18-51$ & $1-28$ & - & - & - & - & $\begin{array}{l}5 \% \text { clinical } \\
\text { evidence of } \\
\text { neuropathy }\end{array}$ & $\begin{array}{l}0-28 \% \\
\text { abnormalities }\end{array}$ & $\begin{array}{l}\text { Abnormalities } \\
\text { related to } \\
\text { duration of } \\
\text { treatment \& } \\
\text { severity of } \\
\text { epilepsy }\end{array}$ \\
\hline
\end{tabular}

11 patients were taking daily doses of between 500 and $800 \mathrm{mg}$.

Another problem is that in every previous report of phenytoin neuropathy other anticonvulsant drugs were also used, and the possible contribution of these drugs to the observed neuropathy was not considered. There have been no clinical studies of peripheral nerve function in patients on monotherapy with phenytoin or other anticonvulsants. A further aspect to consider is the relation of anticonvulsant induced folate deficiency to peripheral nerve dysfunction. ${ }^{20-22}$ This is discussed in detail elsewhere, ${ }^{23}$ and there is evidence that peripheral neuropathy may be one, although not the commonest, of the neuropsychiatric complications of this deficiency state in non-epileptic subjects. ${ }^{24}{ }^{25}$ Finally it is important to consider the relation of duration of anticonvulsant therapy to peripheral nerve dysfunction. Most authors have suggested that the more prolonged the treatment the more likely is neuropathy to develop, ${ }^{7-12}$ although others disagree, ${ }^{13}$ and the evidence is inconclusive. However there have been no prospective studies, nor any investigation of patients recently started on single (or even multiple) drug treatment. In none of the studies of chronic patients has the relation of duration of treatment to such factors as polytherapy, previous acute or chronic toxicity (for example folate deficiency) been taken into account.

In order to control for these problems we undertook the following investigations: (1) an electrophysiological study of sensory nerve function during and after exposure to high serum levels of phenytoin, (2) a clinical and electrophysiological study of previously untreated epileptic patients who had been carefully monitored prospectively on phenytoin or 
Table 2 Patient groups

\begin{tabular}{|c|c|c|c|c|c|c|c|}
\hline \multirow[t]{2}{*}{ Group } & & \multirow[t]{2}{*}{$N$} & \multicolumn{2}{|c|}{ Age (yr) } & \multirow{2}{*}{\multicolumn{2}{|c|}{ Sex }} & \multirow{2}{*}{$\begin{array}{l}\text { Duration of epilepsy } \\
\text { Mean (range) } \\
\text { (yr) }\end{array}$} \\
\hline & & & Mean & Range & & & \\
\hline $\begin{array}{l}\text { A } \\
\mathbf{B} \\
\mathbf{C} \\
\mathbf{D} \\
\mathbf{E}\end{array}$ & $\begin{array}{l}\text { control } \\
\text { phenytoin intoxication } \\
\text { phenytoin } \\
\text { carbamazepine } \\
\text { barbiturate }\end{array}$ & $\begin{array}{r}20 \\
10 \\
32 \\
19 \\
6\end{array}$ & $\begin{array}{l}36 \\
30 \\
30 \\
30 \\
39\end{array}$ & $\begin{array}{l}21-65 \\
12-55 \\
10-67 \\
10-59 \\
24-62\end{array}$ & $\begin{array}{r}5 M \\
5 M \\
14 M \\
10 M \\
2 M\end{array}$ & $\begin{array}{r}15 \mathrm{~F} \\
5 \mathrm{~F} \\
18 \mathrm{~F} \\
9 \mathrm{~F} \\
4 \mathrm{~F}\end{array}$ & $\begin{array}{c}\overline{12} \cdot 0(2-35) \\
3 \cdot 2(1-5) \\
2 \cdot 1(1-3) \\
21 \cdot 0(10-45)\end{array}$ \\
\hline
\end{tabular}

Table 3 Group A: normal controls: clinical and electrophysiological findings

\begin{tabular}{|c|c|c|c|c|c|c|}
\hline & \multirow[t]{2}{*}{ Number } & \multirow{2}{*}{$\begin{array}{l}\text { Incidence of } \\
\text { clinical neuropathy }\end{array}$} & \multicolumn{2}{|l|}{ Sural nerve } & \multicolumn{2}{|c|}{ Median nerve } \\
\hline & & & $\begin{array}{l}\text { Mean CV } \\
\text { (range) }\end{array}$ & $\begin{array}{l}\text { Mean } S A P \\
\text { (range) }\end{array}$ & $\begin{array}{l}\text { Mean } C V \\
\text { (range) }\end{array}$ & $\begin{array}{l}\text { Mean SAP } \\
\text { (range) }\end{array}$ \\
\hline Group A & 20 & $0 \%$ & $\begin{array}{l}48 \\
(40-54)\end{array}$ & $\begin{array}{l}15 \\
(10-22)\end{array}$ & $\begin{array}{l}56 \\
(49-69)\end{array}$ & $\begin{array}{l}18 \\
(10-38)\end{array}$ \\
\hline
\end{tabular}

$\mathrm{CV}=$ conduction velocity $(\mathrm{m} / \mathrm{s})$.

SAP $=$ sensory action potential $(\mu \mathrm{V})$.

carbamazepine monotherapy for 1-5 years, (3) a clinical and electrophysiological study of chronic. epileptic patients on barbiturate monotherapy.

Patients (table 2)

Group A Twenty healthy subjects (age 22-69 yr), who had never taken anticonvulsant drugs, constituted the control group.

Group B Ten chronic epileptic patients taking phenytoin were examined on two occasions (a) with a serum phenytoin level higher than $120 \mu \mathrm{mol} / \mathrm{l}$, and (b) after reduction of the phenytoin level below $80 \mu \mathrm{mol} / \mathrm{l}$.

Group $C$ Thirty-two previously untreated epileptic patients (age 15-68 yr) who had been taking phenytoin alone continuously for 2-5 years, and whose blood level at the time of testing was less than $120 \mu \mathrm{mol} / \mathrm{l}$.

Group $D$ Nineteen previously untreated epileptic patients (age 10-59 yr) who had been taking carbamazepine alone continuously over a period of 1-3 years.

In groups $C$ and $D$ the patients had been regularly supervised by the authors since the commencement of anticonvulsant therapy. Serum drug levels, serum and red cell folate levels had been monitored at frequent intervals. No patient was taking, or had ever taken, any other anticonvulsant drugs.

Group E Six chronic epileptic patients (age 24-62 yr) who were taking regular barbiturate therapy and who had never received any other anticonvulsant drugs. One was examined on two occasions, first when clinically intoxicated and with a phenobarbitone level of $228 \mu \mathrm{mol} / 1$, and again two months later with a level of $95 \mu \mathrm{mol} / \mathrm{l}$.

\section{Methods}

All subjects had a full neurological examination including motor, sensory and reflex functions in the limbs. All epilep- tic subjects had a full blood count, determinations of blood urea, creatinine, electrolytes, sugar, liver function tests, serum proteins, calcium, alkaline phosphatase, vitamin $\mathbf{B}_{\mathbf{1 2}}$, serology and a chest radiograph.

Serum phenytoin and phenobarbitone levels were measured with the on-column methylation method of Kupferberg ${ }^{26}$ using a Hewlett-Packard series 5750 research gas chromatograph, $3 \%$ OV 17 columns and 5-(p-methylphenyl)-5-phenylhydantoinate as the internal standard. Serum carbamazepine was measured by the gas chromatographic method of Toseland et al. ${ }^{27}$ Serum and red blood cell folate levels were measured using the Lactobacillus casei assay.

In every subject the sensory action potentials and conduction velocities of the median and sural nerves were measured according to the method of Burke et al. ${ }^{28}$ Standard electrophysiological techniques for stimulation and recording were employed using surface electrodes and averaging 32 supramaximal evoked potentials using a Medelec MS6 electromyograph. In all cases the proximal sural potentials were obtained from both lower limbs, and median nerve potentials from the index and third fingers of both hands, and the best measurements used. The conduction velocity of the fastest conducting fibres were obtained by dividing the distance from the cathode to the nearest recording electrode by the latency to onset of the first negative deflection. The amplitude of the averaged response was measured peak to peak. The limbs were warmed and the skin temperature was kept at $32^{\circ} \mathrm{C}$ or more in all cases. Scrupulous attention was paid to careful technique as emphasised by Buchthal and Rosenfalck $^{20}$ and Burke et al. ${ }^{20}$

\section{Results}

Group A (control group) No clinical or electrophysiological abnormalities were found. The mean values and range of the median and sural conduction studies are shown in table 3 , and these accord well with the published normal values ${ }^{28} 20$ and with those of our laboratory (Payan, personal communication). 
Table 4 Group B: electrophysiological data during and after phenytoin intoxication

\begin{tabular}{|c|c|c|c|c|c|c|c|c|c|c|}
\hline \multirow[t]{3}{*}{ Case No. } & \multicolumn{5}{|c|}{1 st measurement (phenytoin level $>120 \mathrm{mmol} / \mathrm{l}$} & \multicolumn{5}{|c|}{ 2nd measurement (phenytoin level $<80 \mathrm{mmol} / \mathrm{l}$} \\
\hline & \multirow{2}{*}{$\begin{array}{l}\text { Phenytoin } \\
\text { level } \\
\text { (pmol/l) }\end{array}$} & \multicolumn{2}{|c|}{ Sural nerve } & \multicolumn{2}{|c|}{ Median nerve } & \multirow{2}{*}{$\begin{array}{l}\text { Phenytoin } \\
\text { level } \\
\text { (pmol/l) }\end{array}$} & \multicolumn{2}{|c|}{ Sural nerve } & \multicolumn{2}{|c|}{ Median nerve } \\
\hline & & $\begin{array}{l}C V \\
(m / s)\end{array}$ & $\begin{array}{l}S A P \\
(\mu V)\end{array}$ & $\begin{array}{l}C V \\
(m / s)\end{array}$ & $\begin{array}{l}S A P \\
(\mu V)\end{array}$ & & $\begin{array}{l}C V \\
(\mathrm{~m} / \mathrm{s})\end{array}$ & $\begin{array}{l}S A P \\
(\mu V)\end{array}$ & $\begin{array}{l}C V \\
(\mathrm{~m} / \mathrm{s})\end{array}$ & $\begin{array}{l}S A P \\
(\mu V)\end{array}$ \\
\hline $\begin{array}{c}1 \\
2 \\
3 \\
4 \\
5 \\
6 \\
7 \\
8 \\
9 \\
10 \\
\text { Mean }\end{array}$ & $\begin{array}{l}210 \\
188 \\
164 \\
160 \\
224 \\
132 \\
124 \\
156 \\
152 \\
156 \\
172\end{array}$ & $\begin{array}{l}34 \\
43 \\
40 \\
50 \\
40 \\
38 \\
31 \\
39 \\
40 \\
39 \cdot 4\end{array}$ & $\begin{array}{c}15 \\
16 \\
13 \\
5 \\
\text { Abs } \\
10 \\
15 \\
18 \\
5 \\
8 \\
11 \cdot 7\end{array}$ & $\begin{array}{l}45 \\
51 \\
48 \\
58 \\
50 \\
58 \\
52 \\
48 \\
53 \\
51 \cdot 4\end{array}$ & $\begin{array}{l}25 \\
26 \\
15 \\
18 \\
\text { Abs } \\
15 \\
20 \\
15 \\
10 \\
15 \\
17 \cdot 7\end{array}$ & $\begin{array}{l}* \\
68 \\
48 \\
60 \\
36 \\
52 \\
60 \\
68 \\
76 \\
68 \\
60\end{array}$ & $\begin{array}{l}45 \\
53 \\
40 \\
49 \\
56 \\
52 \\
46 \\
45 \\
48 \\
45 \\
47 \cdot 9\end{array}$ & $\begin{array}{r}19 \\
15 \\
10 \\
8 \\
17 \\
15 \\
12 \\
10 \\
10 \\
12 \\
12 \cdot 8\end{array}$ & $\begin{array}{l}57 \\
64 \\
41 \\
63 \\
67 \\
51 \\
59 \\
53 \\
57 \\
62 \\
57.4\end{array}$ & $\begin{array}{l}22 \\
30 \\
13 \\
18 \\
15 \\
15 \\
20 \\
12 \\
20 \\
18 \\
18 \cdot 3\end{array}$ \\
\hline
\end{tabular}

* Phenytoin discontinued in this patient; Abs = no potential measurable; $\mathrm{CV}=$ conduction velocity; SAP = amplitude of the sensory action potential.

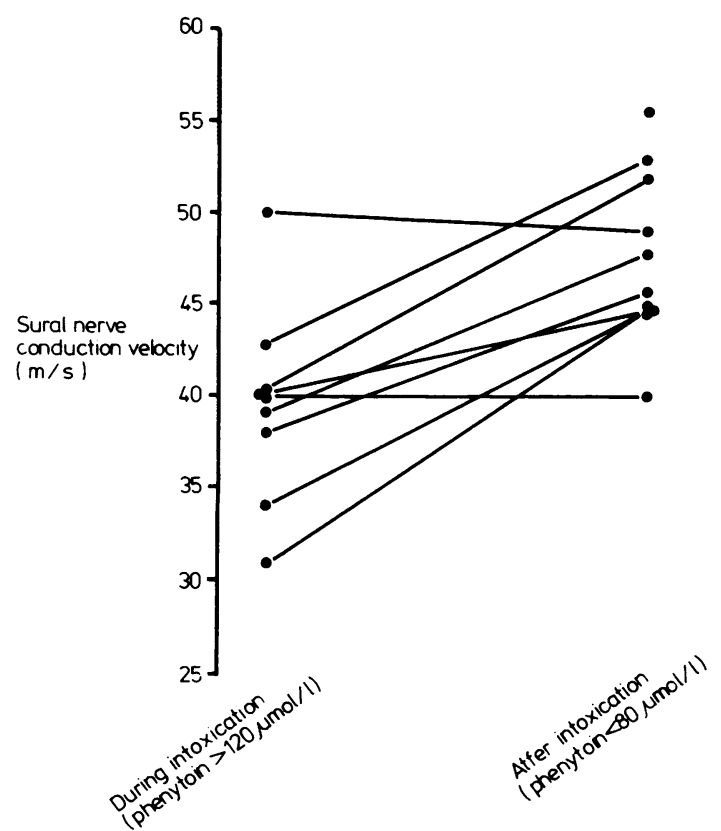

Figure Sural conduction velocity during and after phenytoin intoxication. (See table 4.)

Group $B$ (phenytoin intoxication) (table 4 and fig) Following reduction of high phenytoin levels the mean sural conduction velocity increased from $39.4 \mathrm{~m} / \mathrm{s}$ to $47.9 \mathrm{~m} / \mathrm{s}$ ( $22 \%$ increase), and the mean median conduction velocity from $51.4 \mathrm{~m} / \mathrm{s}$ to 57.4 $\mathrm{m} / \mathrm{s}$ (11\% increase). There was a $15 \%$ or more increase in sural conduction in eight of the 10 cases, and in median nerve conduction in six of the 10 cases. There were no significant changes in the amplitudes of either the median or sural nerve action potentials. At the time of intoxication the sural conduction vel- ocity was subnormal in four cases, the sensory action potential absent in one case and subnormal in three cases, and the median sensory action potential absent in one case. At the time of the second examination all abnormalities had disappeared except for a continuing small sural sensory potential in one patient.

Group C (phenytoin monotherapy) (table 5) There was no clinical evidence of neuropathy in any of the 32 patients examined. In six (18\%) cases, however, electrophysiological abnormalities were found. The sural sensory action potential was abnormal in six cases, with a subnormal conduction velocity in one, and with abnormalities of median nerve conduction in one.

In table 6 , the 26 patients with normal and the six with abnormal electrophysiological findings are compared. At the time of testing no differences were found in the serum phenytoin, serum or red cell folate levels although there were trends towards higher phenytoin and lower folate levels in the electrophysiologically abnormal group. However, the number of patients in the two subgroups with previous exposure to high phenytoin levels, or to low folate levels were different. Sixty-seven per cent of those with abnormal and $14 \%$ of those with normal electrophysiological findings had been previously exposed to high serum phenytoin levels $(\mathrm{p}=<0.01$ $\chi^{2}$ Yates correction); $83 \%$ of those with abnormal and $17 \%$ of those with normal electrophysiological findings had been exposed to subnormal folate levels ( $\mathrm{p}=<0.001 \chi^{2}$ Yates correction). There was no relationship of age, sex or duration of treatment to the electrophysiological findings.

Group D (carbamazepine monotherapy) (table 7) There were no clinical or electrophysiological abnormalities in any of the 19 patients examined. A moderately high carbamazepine blood level (be- 
Table 5 Group C: phenytoin monotherapy

\begin{tabular}{|c|c|c|c|c|c|c|c|}
\hline & \multirow{2}{*}{$\begin{array}{l}\text { Age } \\
(y r)\end{array}$} & \multirow[t]{2}{*}{ Sex } & \multirow{2}{*}{$\begin{array}{l}\text { Duration of } \\
\text { treatment }(y r)\end{array}$} & \multicolumn{2}{|c|}{ Sural nerve } & \multicolumn{2}{|c|}{ Median nerve } \\
\hline & & & & $\begin{array}{l}C V \\
(m / s)\end{array}$ & $\begin{array}{l}S A P \\
(\mu V)\end{array}$ & $\begin{array}{l}C V \\
(m / s)\end{array}$ & $\begin{array}{l}S A P \\
(\mu V)\end{array}$ \\
\hline \multirow{2}{*}{$\begin{array}{l}\text { Electrophysiologically } \\
\text { normal }(n=26) \\
\text { Electrophysiologically } \\
\text { abnormal }(n=6)\end{array}$} & $\begin{array}{l}30 \\
(10-67)^{*}\end{array}$ & $\begin{array}{l}14 \mathrm{~F} \\
12 \mathrm{M}\end{array}$ & $\begin{array}{l}3 \\
(1-5)^{*}\end{array}$ & $\begin{array}{l}48 \\
(6 \cdot 6) \dagger\end{array}$ & $\begin{array}{l}16 \\
(4 \cdot 5) \dagger\end{array}$ & $\begin{array}{l}58 \\
(5 \cdot 5) \dagger\end{array}$ & $\begin{array}{l}21 \\
(5 \cdot 6) \dagger\end{array}$ \\
\hline & $\begin{array}{l}35 \\
17 \\
21 \\
33 \\
60 \\
24\end{array}$ & $\begin{array}{l}F \\
F \\
F \\
M \\
F \\
M\end{array}$ & $\begin{array}{l}4 \\
4 \\
3 \\
2 \\
2 \\
4\end{array}$ & $\begin{array}{l}\overline{42} \\
50 \\
42 \\
38 \\
48\end{array}$ & $\begin{array}{l}\text { abs } \\
8 \\
8 \\
8 \\
5 \\
5\end{array}$ & $\begin{array}{l}57 \\
55 \\
50 \\
55 \\
39 \\
54\end{array}$ & $\begin{array}{l}36 \\
22 \\
18 \\
22 \\
10 \\
14\end{array}$ \\
\hline
\end{tabular}

$\mathrm{CV}=$ conduction velocity.

SAP $=$ sensory action potential.

*Mean (+ range).

tMean $(+\mathrm{SD})$.

Table 6 Group $C$ (phenytoin monotherapy): a comparison of patients with normal ard abnormal electrophysiological findings

\begin{tabular}{|c|c|c|c|c|c|c|}
\hline & \multicolumn{4}{|c|}{ At time of electrophysiological examination } & \multicolumn{2}{|c|}{ Previous recordings } \\
\hline & $\begin{array}{l}\text { Serum } \\
\text { phenytoin: } \\
\text { mean (range) } \\
\text { wmolll }\end{array}$ & $\begin{array}{l}\text { Serum } \\
\text { folate: } \\
\text { mean (range) } \\
\text { ng/ml }\end{array}$ & $\begin{array}{l}\text { Red blood } \\
\text { cell folate } \\
\text { mean (range) } \\
\text { ng/ml }\end{array}$ & $\begin{array}{l}\text { Subnormal } \\
\text { folate* }\end{array}$ & $\begin{array}{l}\text { Serum } \\
\text { phenytoin } \\
\text { over } 80 \text { umol/l }\end{array}$ & $\begin{array}{l}\text { Subnormal } \\
\text { folate }\end{array}$ \\
\hline $\begin{array}{l}\text { Normal } \\
(n=26) \\
\text { Abnormal } \\
(n=6) \\
\text { Significance level }\end{array}$ & $\begin{array}{l}38 \cdot 4 \\
(12-105) \\
50 \\
(14-106) \\
\text { ns }\end{array}$ & $\begin{array}{l}4 \cdot 1 \\
(1 \cdot 4-9 \cdot 9) \\
3 \cdot 2 \\
(1 \cdot 9-7 \cdot 3) \\
\text { ns }\end{array}$ & $\begin{array}{l}346 \\
(185-683) \\
270 \\
(130-396) \\
\text { ns }\end{array}$ & $\begin{array}{l}14 \% \\
60 \% \ddagger \\
\text { ns }\end{array}$ & $\begin{array}{l}14 \% \\
67 \% \\
p=<0.01\end{array}$ & $\begin{array}{l}17 \%+ \\
83 \% \\
p=<0.001\end{array}$ \\
\hline
\end{tabular}

*Subnormal folate: serum folate below $2.0 \mathrm{ng} / \mathrm{ml}$ and/or red blood cell folate below $160 \mathrm{ng} / \mathrm{ml}$.

†n $=23$.

$\neq \mathrm{n}=5$.

Table 7 Group D (carbamazepine monotherapy): clinical and electrophysiological findings

\begin{tabular}{|c|c|c|c|c|c|c|}
\hline & \multirow[t]{2}{*}{ No } & \multirow{2}{*}{$\begin{array}{l}\text { Incidence of } \\
\text { clinical neuropathy }\end{array}$} & \multicolumn{2}{|l|}{ Sural nerve } & \multicolumn{2}{|l|}{ Median nerve } \\
\hline & & & $\begin{array}{l}C V \\
\text { mean (range) }\end{array}$ & $\begin{array}{l}\text { SAP } \\
\text { mean (range) }\end{array}$ & $\begin{array}{l}\mathrm{CV} \\
\text { mean (range) }\end{array}$ & $\begin{array}{l}\text { SAP } \\
\text { mean (range) }\end{array}$ \\
\hline Group D & 19 & $0 \%$ & $\begin{array}{l}49 \\
(43-55)\end{array}$ & $\begin{array}{l}18 \\
(11-32)\end{array}$ & $\begin{array}{l}53 \\
(43-60)\end{array}$ & $\begin{array}{l}18 \\
(9-31)\end{array}$ \\
\hline
\end{tabular}

$\mathrm{CV}=$ conduction velocity $(\mathrm{m} / \mathrm{s})$

SAP $=$ sensory action potential $(\mu \mathrm{V})$.

Table 8 Group G: barbiturate monotherapy

\begin{tabular}{|c|c|c|c|c|c|c|c|c|c|c|c|c|}
\hline \multirow{2}{*}{$\begin{array}{l}\text { Case } \\
\text { No }\end{array}$} & \multirow{2}{*}{$\begin{array}{l}\text { Age } \\
(y r)\end{array}$} & \multirow[t]{2}{*}{ Drug } & \multirow{2}{*}{$\begin{array}{l}\text { Dose } \\
\text { (mgiml) }\end{array}$} & \multirow{2}{*}{$\begin{array}{l}\text { Duration } \\
\text { of therapy } \\
\text { (yr) }\end{array}$} & \multicolumn{2}{|c|}{ Serum levels } & \multirow{2}{*}{$\begin{array}{l}\text { Serum } \\
\text { folate } \\
(\text { nglml })\end{array}$} & \multirow{2}{*}{$\begin{array}{l}\text { Red } \\
\text { blood } \\
\text { cell } \\
\text { folate } \\
(\text { ng/ml) }\end{array}$} & \multicolumn{2}{|c|}{ Sural nerve } & \multicolumn{2}{|c|}{ Median nerve } \\
\hline & & & & & $\begin{array}{l}\text { Pheno- } \\
\text { barbitone } \\
\text { pmolll }\end{array}$ & $\begin{array}{l}\text { Primidone } \\
\text { pmol/l }\end{array}$ & & & $\begin{array}{l}\text { Conduc- } \\
\text { tion } \\
\text { velocity } \\
(\mathrm{m} / \mathrm{s})\end{array}$ & $\begin{array}{l}\text { Sensory } \\
\text { action } \\
\text { potential } \\
(\mu V)\end{array}$ & $\begin{array}{l}\text { Conduc- } \\
\text { tion } \\
\text { velocity } \\
(\mathrm{m} / \mathrm{s})\end{array}$ & $\begin{array}{l}\text { Sensory } \\
\text { action } \\
\text { potential } \\
(\mu V)\end{array}$ \\
\hline \multirow[t]{2}{*}{$\begin{array}{l}1 \\
2 \\
3 \\
4 \\
5 \\
6\end{array}$} & \multirow[t]{2}{*}{$\begin{array}{l}46 \\
62 \\
24 \\
32 \\
30 \\
42\end{array}$} & \multirow[t]{2}{*}{$\begin{array}{l}\text { primidone } \\
\text { primidone } \\
\text { phenobarbitone } \\
\text { primidone } \\
\text { phenobarbitone } \\
\text { (1) phenobarbitone } \\
\text { + primidone } \\
\text { (2) primidone }\end{array}$} & $\begin{array}{r}1500 \\
500 \\
60 \\
1000 \\
60 \\
90 \\
1500\end{array}$ & $\begin{array}{l}26 \\
45 \\
10 \\
20 \\
10 \\
15\end{array}$ & $\begin{array}{r}176 \\
120 \\
107 \\
128 \\
82 \\
228\end{array}$ & $\begin{array}{l}78 \\
37 \\
\frac{2}{23} \\
\frac{73}{73}\end{array}$ & $\begin{array}{l}6.4 \\
3.0 \\
6.8 \\
2.8 \\
\text { ND } \\
\text { ND }\end{array}$ & $\begin{array}{l}777 \\
360 \\
343 \\
190 \\
\text { ND } \\
\text { ND }\end{array}$ & $\begin{array}{l}44 \\
38 \\
57 \\
38 \\
-\end{array}$ & $\begin{array}{l}7 \\
\text { Abs } \\
10 \\
27 \\
12 \\
\text { Abs }\end{array}$ & $\begin{array}{l}48 \\
54 \\
56 \\
60 \\
45 \\
54\end{array}$ & $\begin{array}{r}9 \\
4 \\
11 \\
33 \\
8 \\
19\end{array}$ \\
\hline & & & 1500 & 15 & 95 & - & ND & ND & 46 & 17 & 56 & 24 \\
\hline
\end{tabular}

Case 6 examined on two occasions (1) when intoxicated (2) post intoxication.

$\mathrm{ND}=$ Folate levels not measured; Abs = Absent. 
tween 42-52 $\mu \mathrm{mol} / \mathrm{l})$ had been recorded in four patients (three at the time of testing) and a low serum folate in one patient during their follow up but in none ${ }^{\circ}$ of these were there any electrophysiological abnormalities. There was no relationship of age, sex, duration of treatment, serum carbamazepine, serum or red cell folate levels to any of the electrophysiological data.

Group E (barbiturate monotherapy) (table 8) In two cases there were clinical abnormalities (absent ankle jerks in both and impaired vibration sense in the feet in one). In one patient, case 6 , the sural nerve action potential was absent while the patient was clinically intoxicated (phenobarbitone level 228 $\mu \mathrm{mol} / \mathrm{l})$ and had returned to normal six weeks later when the signs of intoxication had regressed (phenobarbitone level $95 \mu \mathrm{mol} / \mathrm{l}$ ). Of the other five cases, the sural conduction was abnormal in four (abnormal sensory action potential in two and abnormal conduction velocity in two), and median nerve conduction was abnormal in three (subnormal sensory action potential).

\section{Discussion}

We have shown that exposure to high phenytoin levels causes a reversible slowing of sensory nerve conduction velocity (table 4 , fig). Similar changes have been previously reported in animal experiments ${ }^{15}{ }^{17}$ in vitro experiments ${ }^{14}{ }^{16}$ and in motor conduction in human subjects. ${ }^{18}{ }^{10}$ The slowing was greatest in the lower limbs. Fifteen per cent or more reduction of velocity was noted in the sural nerve in eight of the 10 cases and in the median nerve in six of the 10 cases. The mean sural nerve conduction velocity was $22 \%$ lower and the mean median nerve conduction velocity $11 \%$ lower during intoxication. This is comparable to the mean $13 \%$ reduction noted by Birket-Smith and $\mathrm{Krogh}^{19}$ in motor conduction during exposure to high phenytoin levels. A single patient was examined during and after exposure to high barbiturate levels and a similar reversible effect was noted on sural (but not median) conduction, suggesting that the effect is not confined to phenytoin alone. Several patients on carbamazepine monotherapy were examined with moderately high levels but no effect on peripheral nerve function was found.

Previous reports of phenytoin neuropathy have suggested that the incidence of clinical neuropathy varies between $0-33 \%$ and of electrophysiological neuropathy between $0-89 \%$ (table 1 ). The possible reasons for these discordant conclusions have already been referred to and include (1) the failure to recognise the reversible slowing of conduction associated with toxic phenytoin levels (2) the study of selected groups of chronic patients on polytherapy without allowing for the possible contribution of other drugs, and (3) failure to study other factors associated with prolonged therapy. In order to control for these problems as far as possible, we studied epileptic patients (1) who had been newly diagnosed and who had subsequently taken phenytoin or carbamazepine continuously for between 1-5 years, (2) who had no other anticonvulsant drugs, (3) whose serum drug levels and folate status had been prospectively monitored throughout this period, (4) who were not intoxicated at the time of testing, and (5) who had been carefully screened to exclude other potential causes of neuropathy. We were unable to study patients on barbiturate therapy from the onset of treatment, but we were able to include a small group of selected chronic patients who had been on barbiturate monotherapy for many years.

Among the patients we followed prospectively on monotherapy (groups $C$ and D) we found no clinical or electrical abnormalities associated with carbamazepine. However, in the patients on phenytoin, although there were no clinical signs of neuropathy, $18 \%$ had slight electrophysiological abnormalities. Although the small group of patients on barbiturate monotherapy are not strictly comparable because they were selected chronic patients who had not been followed prospectively, nevertheless, it is of considerable interest that two of them had clinical signs of neuropathy and all but one had electrophysiological abnormalities. Further one patient who was reexamined after reduction of a toxic phenobarbitone level also showed improvement in sensory conduction. These observations suggest that phenobarbitone and primidone may, like phenytoin, cause both reversible and more permanent peripheral nerve dysfunction, and cast doubt on many of the reports of phenytoin neuropathy in which barbiturates were a frequent co-medication (table 1).

Among patients on phenytoin monotherapy some interesting differences emerged when the six patients with electrophysiological abnormalities were compared with the remaining 26 without such changes (table 5). The abnormal subgroup had significantly more past evidence of exposure to toxic levels of the drug and to low folate levels. This suggests the possibility that permanent neuropathy due to this drug (and perhaps barbiturates) may result from prolonged or repeated episodes of intoxication or folate deficiency. This would be consistent with the studies reporting a high incidence of clinical neuropathy in chronic epileptic patients who had a frequent history of past toxicity or high drug levels at the time of testing. ${ }^{912}$ There is evidence that severe folate deficiency in non-epileptic subjects may lead to peripheral neuropathy, amongst other neuro- 
psychiatric complications, ${ }^{24} 25$ and the relationship of the generally milder prolonged anticonvulsant induced folate deficiency to neuropathy in epileptic patients is discussed elsewhere. ${ }^{22} 23$

The pathophysiological basis of anticonvulsant neuropathy is obscure. The predominant electrophysiological change amongst the patients taking phenytoin at therapeutic levels was a reduction in the amplitude of the sensory action potential with relative preservation of the conduction velocity, and this contrasts with the moderate slowing of conduction noted amongst those intoxicated with phenytoin. This suggests that the two effects on the peripheral nerve are distinct, although repeated episodes of the latter may ultimately lead to the former.

Finally although the duration of follow-up of our patients on phenytoin or carbamazepine is relatively short (1-5 years) our observations to date suggest that anticonvulsant neuropathy, as with other chronic complications of antiepileptic therapy, could be greatly reduced by careful monitoring of single drug treatment and the avoidance as far as possible of acute toxicity or polytherapy. ${ }^{30}$

We are very grateful to $\mathrm{Dr} \mathbf{J}$ Payan for technical advice and valuable discussion.

\section{References}

${ }^{1}$ Boschi E, Menozzi G. Polinevriti da idantoina. Sistema Nervosa 1965;17:395-401.

${ }^{2}$ Dobkin BH. Reversible subacute peripheral neuropathy induced by phenytoin. Arch Neurol 1977;34:189-90.

${ }^{3}$ Finkelman J, Arieff AJ. Untoward effects of phenytoin sodium in epilepsy. JAMA 1942;118:1209-12.

- Meienberg O, Bajc O. Akute Polyneuropathie durch Diphenylhydantoin-intoxikation. Disch Med Wochenschr 1975;100:1532-9.

s Michaux L, Feld M, Iabet K. L'intoxication par les hydantoines: Manifestations neurologiques. Presse Med 1959;67:2010-2.

- Brumlik J, Moretti L. The effect of Diphenylhydantoin on nerve conduction velocity. Neurology (Minneap) 1966;16:1217-8.

${ }^{7}$ Chokrovierty S, Sayeed ZA. Motor nerve conduction study in patients on diphenylhydantoin therapy. $J$ Neurol Neurosurg Psychiatry 1975;38:1235-9.

- DeCastro JHX, Acosta ML, Sica REP, Guerico N. Sensory and motor nerve conduction velocity in long-term diphenylhydantoin therapy. Arq Neuropsiquitr (Sao Paulo) 1972;30:215-20.

- Eisen AA, Woods JF, Sherwin AL. Peripheral nerve function in long-term therapy with diphenylhydantoin. Neurology (Minneap) 1974;24:411-7.

${ }^{10}$ Encinoza $O$. Nerve conduction velocity in patients on long-term diphenylhydantoin therapy. Epilepsia 1974;15:147-54.

1 Fujiwara T, Seko K, Akiguchi I, Yamada N, Iwai N. Peripheral nerve function in patients with long-term anticonvulsant therapy. Clinical Neurology (Jpn) 1979;19:735-43.

${ }^{12}$ Lovelace RE, Horwitz SJ. Peripheral neuropathy in longterm diphenylhydantoin therapy. Arch Neurol 1968;18:69-77.

${ }^{13}$ Zebrowska-Szymusik M. Effect of phenytoin on peripheral motor neuron. Neurol Neurochir Pol 1978;12:427-34.

${ }^{14}$ Korey S. Effect of Dilantin and Mesantoin on the giant axon of the squid. Proc Soc Exp Biol Med 1951;76:297-9.

15 Le Quesne PM, Goldberg V, Vajda F. Acute conduction velocity changes in guinea-pigs after administration of diphenylhydantoin. J Neurol Neurosurg Psychiatry 1976;39:995-1000.

${ }^{16}$ Morell F, Bradley W, Ptashne M. Effect of diphenylhydantoin on peripheral nerve. Neurology (Minneap) 1958;8:140-4.

${ }^{17}$ Toman J. The neuropharmacology of antiepileptics. Electroencephalogr Clin Neurophysiol 1949;1:33-44.

${ }^{18}$ Hopf HC. Uber die Veranderung der Leitfunktion peripherer motorischer nervenfasern durch Diphenylhydantoin. Dtsch Z Nerv 1968;193:41-56.

10 Birket-Smith E, Krogh E. Motor nerve conduction velocity during diphenylhydantoin intoxication. Acta Neurol Scand 1971;47:265-71.

${ }^{20}$ Horwitz SJ, Klipstein FA, Lovelace RE. Relation of abnormal folate metabolism to neuropathy developing during anticonvulsant drug therapy. Lancet 1968; 1:563-5.

${ }^{21}$ Reynolds EH. Chronic antiepileptic toxicity: A review. Epilepsia 1975;16:319-52.

22 Martinez-Figueroa A, Johnson RH, Lambie DG, Shakir RA. The role of folate deficiency in the development of peripheral neuropathy caused by anticonvulsants. $J$ Neurol Sci 1980;48:315-23.

* Shorvon SD. Anticonvulsant therapy and peripheral neuropathy. In: Botez MI, Reynolds EH, eds. Folic Acid in Neurology, Psychiatry and Internal Medicine. New York: Raven Press, 1979:335-46.

s Shorvon SD, Reynolds EH. Folate deficiency and peripheral neuropathy. In: Botez M, Reynolds EH, eds. Folic Acid in Neurology, Psychiatry and Internal Medicine. New York: Raven Press, 1979:413-21.

${ }^{25}$ Shorvon SD, Carney MWP, Chanarin I, Reynolds EH. The neuropsychiatry of megaloblastic anaemia. $\mathrm{Br} \mathrm{Med}$ $J$ 1980;281:1036-8.

${ }^{28}$ Kupferberg HJ. Quantitative estimation of diphenylhydantoin primidone and phenobarbital by gas-liquid chromatography. Clin Chem Acta 1970;29:283-8.

${ }^{27}$ Toseland P, Grove J, Berry D. An isothermal GLC determination of the plasma levels of carbamazepine, diphenylhydantoin, phenobarbitone and primidone. Clin Chem Acta 1972;38:321-8.

20 Burke D, Skuse N, Lethlean A. Sensory conduction of the sural nerve in polyneuropathy. $J$ Neurol Neurosurg Psychiatry 1974;37:647-52.

20 Buchthal F, Rosenfalck A. Evoked action potentials and conduction velocity in human sensory nerves. Brain Res 1966;3:1-122.

${ }^{30}$ Reynolds EH, Shorvon SD. Monotherapy or polytherapy for epilepsy? Epilepsia $1981 ; 22: 1-10$. 